\title{
A Study of Irrigation Performance Index and Real Cost Value of Irrigation Operations and Maintenance in Surak Irrigation Area
}

\author{
Tri Budi Prayogo, Sri Wahyuni, Muhammad Iqbal* \\ Water Resources Engineering Department, Brawijaya University, Malang, 65145, \\ Indonesia \\ muhammdiqbl@gmail.com
}

Received 16-09-2020; accepted 14-01-2021

\begin{abstract}
Irrigation Asset Management is required to maintain the value of irrigation asset function and condition. Surak Irrigation Area is located in Lawang Sub-District, Malang Regency. The novelty of this research is the finding of priority to improve irrigation assets equipped with a budget. After resurveying in 2020, 21 points of damaged infrastructure were found in Surak Irrigation Area. The irrigation performance index was found to be $78 \%$ (good condition) with the details were as follows: the physical infrastructure aspect was $39 \%$, the water availability aspect was $5 \%$, the planting index aspect was $4 \%$, the supporting facilities for operation and management aspect was $8 \%$, the organizational and personnel aspect is $11 \%$, the documentation aspect was 4\%, and the Water User Association aspect was 7\%. Priority calculation utilized the ranking method, which ranks asset values from the lowest to the highest. The result was that 24 assets are in good condition, 43 assets are in good condition, and 146 are in excellent condition. The real cost value of irrigation operations and maintenance was calculated to be IDR $1,561,742,000$ with IDR $208,507,000$ for operating costs and IDR $1,353,235,000$ for maintenance costs. For rehabilitation, it was found that 24 assets need regular maintenance and repair, 24 assets need regular maintenance, and 146 assets need routine maintenance.
\end{abstract}

Keywords: asset management, irrigation, performance index, rehabilitation priority

\section{Introduction}

Irrigation is a crucial factor for maximizing the potential of agriculture productivity to meet food demands. Despite the vital position of irrigation in food demands, irrigated crops contribute to $21 \%$ of the total agricultural area and consume $69 \%$ of withdrawn water resources worldwide (AQUASTAT) [1]. Therefore, the agricultural sector has enormous water consumption. The water consumption often leads to surface and groundwater resource depletion in irrigated perimeters, which harms ecosystems and prejudices water access and food security. Therefore, the sound management of water resources in

Cite this as: Prayogo, T. B., Wahyuni, S., \& Iqbal, M. (2021). A Study of Irrigation Performance Index and Real Cost Value of Irrigation Operations and Maintenance in Surak Irrigation Area. Civil and Environmental Science Journal (Civense), 4(1), 30-42. doi: https://doi.org/10.21776/ub.civense.2021.00401.4 
irrigated agriculture is key to sustainable development. Irrigation asset management is required for the management of physical and non-physical assets contained in irrigation areas. A widespread study on water management led to two relevant concluding statements as follows; 1) It is impossible to feed a fast-growing population with improved living conditions in a region with existing low-level water management and agricultural trends"; 2) "Food security is achievable with the existing resources in 2025 if and only if the implementation of proper water management measures is realized" [2]. The food demand in Indonesia is supported by Indonesia's irrigation policy reform that generated an overall sustained positive impact [3]. With expanding coverage and rising implementation quality, rice production is likely to increase further. According to one study, maintenance in irrigation has helped improve an irrigation system [4].

Nevertheless, the improved condition did not elevate the overall declining condition of the irrigation system. By carrying optimal management of irrigation assets, the efficient steps can be determined to extend and maintain asset conditions, determine the priority of assets that require rehabilitation, and estimate the costs incurred for rehabilitation [5]. Surak Irrigation Area is located in Lawang Sub-District, Malang Regency, and its primary channel extends across to Purwosari Sub-District, Pasuruan Regency. From the obtained preliminary data, there were damages to structures and channels in the area, which causes suboptimal performance of the Surak Irrigation Area.

\section{Materials and Methods}

\subsection{Study Location}

The location of the study is the Surak Irrigation Area in Lawang Sub-District, Malang Regency. The intake of Surak is the Surak Dam, located in Lawang Sub-District, Malang Regency, and the primary irrigation channel flows alongside the national road to the north until Purwosari Sub-District, Pasuruan Regency.

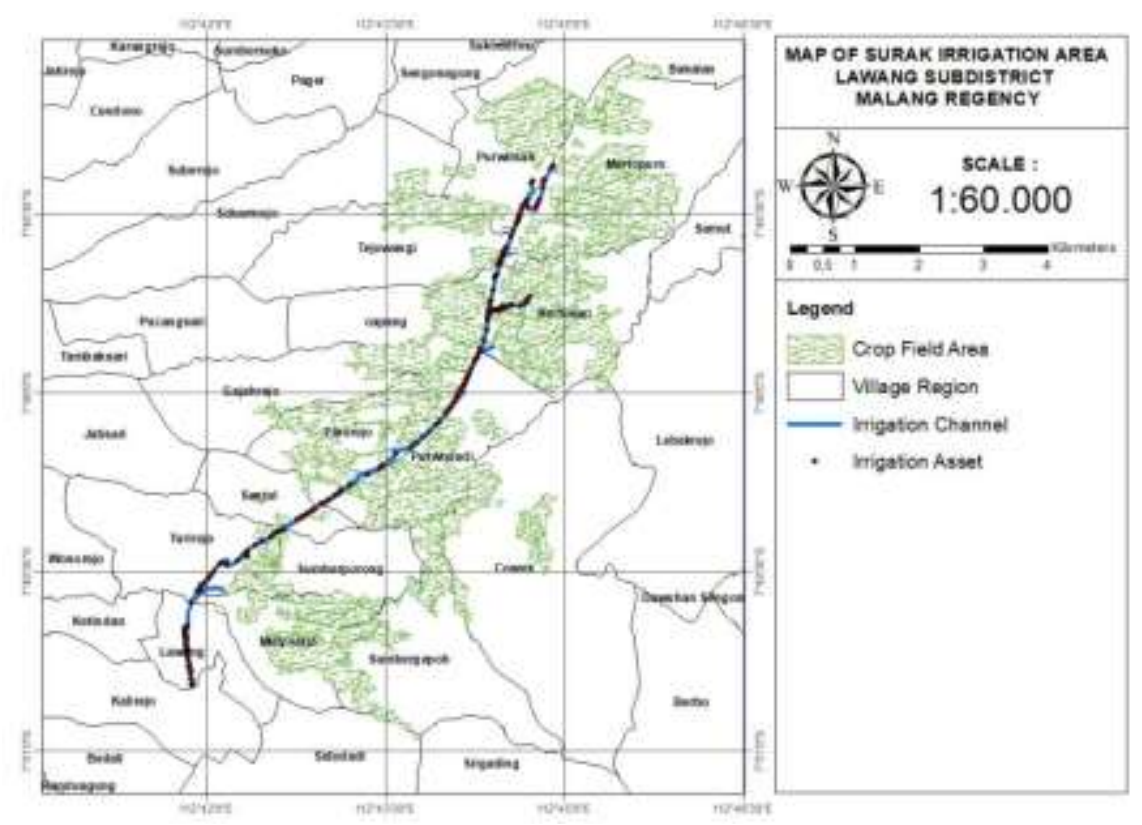

Figure 1. Location of Study

The Surak Irrigation Area's potential area is $875 \mathrm{Ha}$, and its functional area is $795 \mathrm{Ha}$. The water resources in Surak Irrigation Area are taken from the Surak River. The Surak Irrigation Area is located in the Brantas River Basin. 


\subsection{Primary and Secondary Data Collection}

The following are the data required in conducting this study:

1. Identity Data of Surak Irrigation Area

2. Physical Asset Infrastructure Data

3. Water Availability Data from 2017 to 2019

4. Crop Productivity Data from 2017 to 2019

5. Data on Supporting Facilities for Operations and Maintenance

6. Organization and Personnel Data

7. Documentation Data

8. Data of Water User Associations (WUAs)

9. Data on Wages and Material Costs in 2019

\subsection{Stages of the Study}

1. Primary and secondary data collection

2. Survey of Surak Irrigation Area

3. Calculation of Irrigation Performance Index
a. Physical Infrastructure aspect
b. Water Availability aspect
c. Crop Productivity aspect
d. Supporting Facilities aspect
e. Personnel Organization aspect
f. Documentation aspect
g. Water User Associations (WUAs) aspect

4. Priority ordering of physical infrastructure assets

5. Calculation of Real Cost Value of Irrigation Operation and Maintenance

6. Rehabilitation of Irrigation Assets

\subsection{Survey of Surak Irrigation Area}

Surveying the Surak Irrigation Area was the first of many steps to obtain primary data from the field. Data regarding dimensions, conditions, functions, coordinates, and documentation were obtained by carrying out the survey. The survey was carried out from the intake structure to the last tapping structure on the irrigation area channel.

\subsection{Irrigation Performance Index}

Irrigation project performance evaluation is critical and vital to ensure the sustainability of irrigated agriculture [6]. There is a wide range of choices for characterizing all aspects of performance evaluation; nevertheless, there is still no agreed approach and framework to assess and evaluate irrigation performance. The irrigation performance index measures performance when planning an irrigation area and its performance level when implementing its operations and maintenance. [7].

Table 1. Percentage Weights of the Irrigation Performance Index

\begin{tabular}{|c|c|}
\hline Aspect & $\%$ \\
\hline Physical Infrastructure & 45 \\
\hline Water Resource Availability & 9 \\
\hline Crop Productivity & 6 \\
\hline Supporting Facilities & 10 \\
\hline Personnel Organization & 15 \\
\hline Documentation & 5 \\
\hline Water User Associations (WUAs) & 10 \\
\hline Total & 100 \\
\hline
\end{tabular}




\subsubsection{Physical Infrastructure}

What is meant by physical infrastructure is structure assets or channels in the Surak Irrigation Area. The parameters included as aspects of physical infrastructure are channels, drainage channels, water level regulators, complementary structures, inspection roads, and offices and warehouses.

\subsubsection{Water Resource Availability}

Water scarcity is a mounting challenge in many parts of the world, resulting from growing demand from different sources, including agriculture, mining, industry, hydroelectricity generation, and a rising population [8]. Therefore, water resource availability is an essential aspect of irrigation performance assessment. Water resource availability is defined as the fulfillment of irrigation water resource demands or the $\mathrm{K}$ factor calculation. This calculation is based on the average $\mathrm{K}$ factor in the first, second, and third planting seasons.

\subsubsection{Crop Productivity}

The crop productivity aspect is divided into two parts: the actual planting area and rice productivity. The actual planting area aspect is calculated based on the comparison percentage of the actual planting area and the standard or potential area in the first, second, and third planting seasons. Meanwhile, rice productivity compares actual rice productivity and the national average rice productivity $(6.13 \mathrm{tons} / \mathrm{ha})$ in the first, second, and third planting seasons.

\subsubsection{Supporting Facilities}

To support various operational and maintenance activities of irrigation areas, it is necessary to possess equipment, transportation, communication tools, and execution offices to be perused by personnel on the field. For this aspect, the condition and percentage of operational support and maintenance facilities that can assist activities in the area were assessed.

\subsubsection{Personnel Organization}

For this aspect, the structural organization that carries out operations and maintenance of irrigation was assessed based on its legality, personnel sufficiency on the field, and existing personnel's employment status.

\subsubsection{Documentation}

To make it easier to carry out a survey or census on the field, documentation for the irrigation area is essential. The documentation aspect assesses the completeness of existing documents such as data books, maps, drawings, and irrigation network schemes for the irrigation area.

\subsubsection{Water User Associations (WUAs)}

Typical common-pool irrigation systems are characterized by the rivalry of consumption and exclusion difficulty if not correctly administered. Therefore, it is essential for irrigation management to perform collective actions based on farmers' collaborative efforts or cooperation in rural communities, for example, through Water User Associations (WUAs) [9].

Transferring irrigation management responsibilities from government agencies to farmers has been essential in many countries [10]. As a result, farmers' participation, especially in WUAs in irrigation management, has taken center stage. The irrigators who were considered beneficiaries are now considered partners in the planning, development, operations, and maintenance of irrigation systems.

A study found that it is crucial to create an enabling environment to enable farmers to realize profits and other economic benefits to participate in irrigation infrastructure maintenance [11]. Development agents should also create farmer organizations to improve farmer cohesion and social capital to 
participate in collective irrigation infrastructure maintenance. The evaluation of WUA performance is an important management tool to aid in providing a good irrigation service because it may support the system management in the identification of the strengths and weaknesses of an organization as well as the improvement of organizational performance and productivity, taking into account its objectives [8]. The values of the aspect of WUAs were determined based on the status and legality of WUA Associations, the institutional condition of WUA Associations, frequency of meetings of WUAs with their observers or branches, active participation of WUAs in surveys, WUA participation in irrigation network repair or maintenance and natural disaster rehabilitation, WUA fees for the repair and maintenance of tertiary plots, and WUA participation in crop planning and water allocation.

\subsection{The priority of Irrigation Asset Rehabilitation}

The priority of irrigation asset rehabilitation was determined by calculating the physical infrastructure aspect with the ranking method. Sorting the condition values from the smallest to the largest allows priority to be distinguished from the irrigation area's rehabilitation of assets.

\subsection{Calculation of Real Cost Value of Irrigation Operations and Maintenance}

The teal cost value of irrigation operation and maintenance is divided into operations and maintenance costs. The two aspects are then further divided into several other elements: overtime wages, office supplies, lubricants and paints for sluice gates, heavy equipment, business trips, and periodic maintenance. The costs of every item are assessed and controlled based on location and value [12].

\subsubsection{Overtime Wage}

The overtime wage aspect in an irrigation area is based on the number of observers, sluice guards, weir operational officers, and field staff assistants. The rate of the wage is different among staff members and follows the regulations specified in the area.

\subsubsection{Field Materials for Subsections of an Irrigation Area}

Field materials for subsections of the irrigation area are based on the operations and maintenance manual. The calculation consists of fuel, materials for sluice gate maintenance, fieldwork supplies, materials for work residence maintenance, and self-managed maintenance materials.

\subsubsection{Lubricants and Paints for Sluice Gates}

To maintain the condition of existing sluice gates in irrigation infrastructures, it is necessary to have lubricants and paints for sluice gates based on the number of sluice gates following the field's inventory. The material demand varies depending on the type and dimensions of the sluice gates.

\subsubsection{Heavy Equipment and Tools for Subsections of an Irrigation Area}

Heavy equipment and tools for an irrigation area's subsections is the cost needed to obtain vehicles and field tools. These are necessary to deploy sluice guards, weir operational officers, and observers.

\subsubsection{Business Trips for Regional Technical Implementation Unit Staff, Observers, Sluice Guards, and Weir Operational Officers}

Calculation of business trips for Regional Technical Implementation Unit staff, observers, sluice guards, and weir operational officers is based on the frequency of business trips and the number of people.

\subsubsection{Other Expenditures for Regional Technical Implementation Unit Staff, Observers, Sluice Guards, and Weir Operational Officers}

Other expenditures for Regional Technical Implementation Unit staff, observers, sluice guards, and weir operational officers involve operation and maintenance costs (for operational vehicle documents, 
costs of printing blanks for operation and maintenance activities, photocopy expenses, meeting and food costs, coaching, and training costs, cropping plan preparation costs, and emergency maintenance costs).

\subsubsection{Periodic Maintenance}

It is defined as calculating the costs required to maintain physical infrastructure assets in an irrigation area. The calculation of the volume and area of damage from each asset in an irrigation area is obtained by calculating dimensions during the survey. Analysis of periodic maintenance costs can be divided into two calculations: channel damage and structural damage.

In the channel, the damage that occurs can damage the lining, or transported sediment, garbage, or mud that clogs the irrigation channel. Meanwhile, structural damage concerns the need to replace or rehabilitate damaged sluice gates, repairs to structural portions, cleanup of household waste or weeds, and transported sediment, mud, or debris stuck to the sluice gates.

After obtaining the volume and extent of damage in the channels or structures, the costs needed to carry out periodic maintenance can be calculated. The calculation is based on the analysis of the work unit price of different jobs and items.

The work that needs to be carried out for channel and structure rehabilitation consists of plasterwork $\left(\mathrm{m}^{2}\right)$, excavation of sediment $\left(\mathrm{m}^{3}\right)$, river masonry installation $\left(\mathrm{m}^{3}\right)$, lining masonry installation $\left(\mathrm{m}^{3}\right)$, replacement of old lining with new lining $\left(\mathrm{m}^{3}\right)$, and weed clearing $\left(\mathrm{m}^{2}\right)$.

For damage to structures that require replacement of the sluice gates, installation is carried out according to the sluice gates' dimensions and type. The cost prices of materials and wages are according to the location where the work is carried out. After calculating the periodic maintenance, a summary of the real cost value of irrigation operations and maintenance can be made. The costs required to carry out operations and maintenance in an irrigation area can then be found.

\subsection{Rehabilitation of Physical Infrastructure Assets in Irrigation Area}

The rehabilitation of physical infrastructure assets is based on each of the assets [13]. Assets with performance indices between $90-100 \%$ require routine maintenance, between $80-90 \%$ require periodic maintenance, between $60-80 \%$ require periodic repair, and below $60 \%$ require periodic maintenance in the form of rehabilitation or replacement.

\section{Results and Discussion}

There are many methods to calculate the Irrigation Performance Index value. The difference of the technique lies between the parameter and percentage in each of the aspects. Irrigation Performance Index can be calculated using the software as such as PDSDA-PAI 1.0 or 2.0, web-based application e-PAKSI, Fuzzy set theory, direct measurements for indicators, Analysis Hierarchy Process (AHP), and Remote Sensing (RS although they offer a wide range of choices for characterizing all aspects of performance evaluation. However, still, no agreed approach could be provided to assess the performance of different irrigation systems. It could be concluded that the selection of the evaluation framework and method primarily depends on the nature of the irrigation system and the purpose of evaluation., the assessment was based upon the Performance Index Assessment Guide (Revision no. 1) that was published as a guide by the Water Resources Department in 2019. This assessment guide is derived from the Irrigation Performance Index Assessment based by the Ministry of Public Works and Public Housing no. 32/2007. The six aspects of the assessment are Physical Infrastructure Water Resource Availability, Crop Productivity, Supporting Facilities, Personnel Organization, Documentation, Water User Associations (WUAs). From previous research in Barugbug Irrigation Area based on the method from no 32/2007, the result was valued at 74,24\% and categorized in good condition.[14] Additionally, using the same approach in Pungkit Irrigation Area by Sijoen using PDSDA-PAI V.1.0 that based on the same method, the result obtained valued at $68,68 \%$ and categorized in mediocre condition. [15]. 
The assessment guide provides a much more detailed assessment per aspect to estimate the irrigation condition's value than using the number 32/2007 method, such as filling percentage in the form without an explicit parameter. One of the many clear examples of the detailed parameter in the guide is the weir crest aspect. The following aspect divided into four assessments: weir condition, seepage, surface condition, and pillar in the drainage gate. Every aspect has a different percentage of $60 \%, 10 \%, 10 \%$, and $20 \%$, respectively. In each element, there are four categories of conditions. It depends on the assessment of the quality of the weir. Four types rely on the field's review: Excellent (100-90\%), Good $(80 \leq 90 \%)$, Average $(60 \leq 80 \%)$, and Poor $(>60 \%)$. For weir condition to categorize in excellent condition, it must have a perfect and intact weir without a decrease in elevation. Otherwise, to be classified in poor condition, it must have poor, perforated, and peeled surface condition. For this reason, using this detailed guide to assessing the parameter in each aspect will decrease the bias of the surveyor since it has a clear understanding of the assessment.

The condition result of the Irrigation Performance Index assessment is different according to the method that has been used. As stated in method number 32/2007, an excellent condition valued at $100-80 \%$, good condition at $79-70 \%$, mediocre condition at $69-55 \%$, and poor condition for value below $55 \%$. [14]. This range value of categories is different from the guide assessment and will differentiate the assessment condition.

\subsection{Existing Channel Condition of Surak Irrigation Area}

After surveying the Surak Irrigation Area in 2020, there were 21 location points of damage. The 21 damage points can be categorized according to their types. They are comprised of 1 illegal structure in the middle of the channel, 14 points of damaged lining, and 6 points filled with sediment and household waste. The majority of the damage occurred in section 1 of the Surak Primary Channel, with eight damage points.

\subsection{Irrigation Performance Index Calculation}

\subsubsection{Physical Infrastructure}

The physical infrastructure assets in the Surak irrigation area scored $39.1 \%$ from a maximum of $45 \%$. The score of $39.1 \%$ is made up of the aspects of the intake structure that scored $12.8 \%$ from the maximum of $13 \%$, the channel that scored $8.4 \%$ out of $10 \%$, channel structures that scored $6.8 \%$ out of $9 \%$, drainage and structures that scored $2.8 \%$ out of $4 \%$, inspection roads that scored the maximum of $4 \%$, and housing, offices, and warehouses that scored $4.4 \%$ from the maximum of $5 \%$.

The intake structure score of $12.8 \%$ was obtained from the weir aspects that scored $3.8 \%$, the weir sediment gate and gears that scored $7 \%$, and the sediment trap and drain gate that scored $2 \%$.

The irrigation channel score of $8.4 \%$ was obtained from the average condition of the existing channel in Surak Irrigation Area. The aspects assessed for the irrigation channel were the shift in the channel profile, the number of illegal taps and leaks, sediment or erosion that affect its capacity, height and stability of the embankment, slope or wall conditions, and channel rehabilitation.

Regulatory and complementary structures scored $6.8 \%$, which was obtained from the aspects of regulatory structures that scored $1.7 \%$, discharge measurement structures that scored $2.04 \%$, complementary structures that scored $1.76 \%$, and structure rehabilitation that scored $1.28 \%$. The regulating structure aspect scored $1.7 \%$, obtained from primary and secondary channel structures that scored $0.9 \%$, and tertiary tapping structures that scored $0.8 \%$.

The aspect of discharge measurement structures scored $2.04 \%$, which was obtained from the structure's aspects that scored $0.86 \%$, individual measurement structure that scored $0.73 \%$, and individual tertiary tapping structures that scored $0.45 \%$. The aspect of complementary structures scored $1.76 \%$, which was obtained from an average asset value that scored $0.72 \%$ and wastes conditions that scored $1.04 \%$. 
The aspect of inspection roads for Surak Irrigation Area scored the maximum of $4 \%$. The maximum score is that Surak Irrigation Area is located along a national highway, making it easier to access channels and structures. Only a few secondary sections require walking to reach them.

The aspect of housing, offices, and warehouses scored $4.4 \%$ out of $5 \%$. The Regional Technical Implementation Unit of Pekalen River Basin in the City of Pasuruan, which manages the Surak Irrigation Area, had $2 \%$ for the office aspect, $0.8 \%$ for the housing aspect, and $1.6 \%$ for the warehouse aspect.

\subsubsection{Water Resource Availability}

The aspect of water resources availability in the Surak Irrigation Area scored 5.4\% out of the maximum of $9 \%$. The $\mathrm{K}$ factor calculations for the entire year of 2019 showed that planting season I was 0.59 , planting season II was 0.43 , and planting season III was 0.39 . Following the criteria and weight of irrigation performance assessment, the Surak Irrigation Area has a reasonably small $\mathrm{K}$ factor. The first, second, and third planting seasons are less than 0.6. This condition is categorized as $\operatorname{Bad}(<60 \%)$ based on the irrigation system's performance appraisal criteria and weight.

\subsubsection{Crop Productivity}

The actual crop index is the percentage ratio between the planted area and the irrigated area's total area. Calculations for the entire year of 2019 showed that the averages were $89.3 \%$ for planting season I, $86.8 \%$ for planting season II, and $4.9 \%$ for planting season III. Comparing the actual planting area and the standard area for planting seasons I, II, and III is $<60 \%$. Thus, according to the criteria and weight of the irrigation system performance appraisal, it can be concluded that the actual planted area in the Surak Irrigation Area is categorized to be in bad condition.

Crop productivity is the percentage that becomes the parameter for paddy productivity in tons per hectare. In the irrigation system performance of evaluation weight criteria, rice productivity is parameterized as the comparison percentage of actual crop productivity to the national average rice productivity (6.13 tons/ha) in planting seasons I, II, and III. According to the data available at the Regional Technical Implementation Unit of Pekalen River Basin, the Surak Irrigation Area, located in Purwosari Sub-District, has crop productivity of 7.5 tons/ha.

\subsubsection{Supporting Facilities}

Data for the aspect of supporting facilities obtained from interviews and surveys showed that the percentage for the number of personnel reaches $100 \%$, which in other words is sufficient. Almost all of them are in good condition, and they received a maximum score of $0.5 \%$. There is still no heavy equipment that can support the operation and maintenance of the Surak Irrigation Area, and therefore the score for the heavy equipment aspect is $0.9 \%$. The accumulated score for the operation and maintenance aspect was $3.4 \%$, from a maximum of $4 \%$.

There is still no transportation available at the Regional Technical Implementation Unit to support operations and maintenance for the transportation aspect, which has a weight of $2 \%$ for the Surak Irrigation Area. As a result, the transportation aspect is categorized in bad condition $(<60 \%)$ with a score of $1.2 \%$ out of $2 \%$.

The office equipment and furniture at the Regional Technical Implementation Unit of Pekalen River Basin can be complete. There are desks, chairs, file cabinets, filing shelves, filing cabinets, computers, calculators, and stationery; almost all are in good condition. Thus, supporting equipment for office and operations received a maximum score of $2 \%$.

Communication equipment that can support operations and maintenance in the Surak Irrigation Area, such as Radio, SSB, walkie-talkies, and cell phones, still has not been provided by the Regional Technical Implementation Unit of Pekalen River Basin. Even though the officers in the field have access to a good communication network, these must still be provided by themselves.

Therefore, communication equipment is categorized as being in bad condition $(<60 \%)$ and received a score of $1.2 \%$ out of $2 \%$. The accumulated score for supporting facilities for operations and 
maintenance in the Surak Irrigation Area was $7.8 \%$ out of the maximum of $10 \%$. This aspect is categorized as good $(60-80 \%)$.

\subsubsection{Personnel Organization}

From the results of interviews conducted with observers, sluice guards, and weir operational officers representing the Surak Irrigation Area, it was found that the frequency of routine meetings to discuss irrigation operations and maintenance issues was adequate, and they had carried out their duties following the operations and maintenance manual. From the interviews and observations, a score of $3.82 \%$ from $5 \%$ was obtained for organizational structure and maintenance.

One observer's demand was met, but one weir officer's need was not met, while the demand for four sluice guards was also completed. Thus, the score was $2.5 \%$ from a maximum of $4 \%$. Meanwhile, the observer's employment status is a civil servant, and one of the sluice guards and weir operational officers is a civil servant, which earned a score of $1.8 \%$ out of the maximum of $2 \%$.

To find out how much the observers, guards, and weir operational officers understood their tasks and functions, a questionnaire was distributed containing ten questions about Irrigation Operations and Maintenance's understanding. Each question weights $10 \%$, which is then categorized again into several levels based on the answers given.

From the results of the questionnaire, the average understanding of operations and maintenance for observers (75\%) and guards and weir operational officer (65\%) were categorized as good (60-80\%). The data entry and reporting were carried out in an orderly, correct, and valid manner. For the personnel, the total score for understanding tasks and functions, and the frequency of training implementation and data input was $6.98 \%$ out of the maximum of $10 \%$. The fundamental aspect of personnel organization attained a score of $10.8 \%$ out of the maximum of $15 \%$.

\subsubsection{Documentation}

From the survey results at the Regional Technical Implementation Unit office of Pekalen River Basin to collect documentation data for the Surak Irrigation Area, only several available documentation data were obtained, such as a map of the irrigation network scheme. There was still no printed documentation data on the office walls. The as-built drawings and maintenance maps even could not be provided. The Surak Irrigation Area's authority had just been transferred from the Regional Technical Implementation Unit of Purwosari to the Regional Technical Implementation Unit of Pekalen River Basin. For these two aspects, because the Irrigation Area Data Book was still not available, the condition is categorized as bad $(<60 \%)$ and scored $1.2 \%$ out of $2 \%$. For Maps and Figures, they scored $2.6 \%$ out of $3 \%$ because schematic drawings were available. The total score for the documentation aspect was $3.8 \%$ out of the maximum of $5 \%$.

\subsubsection{Water User Associations (WUAs)}

For the first aspect, the Alliance of Water User Associations (WUAs) of Tirto Makmur did not have association articles. Thus it is categorized in bad condition $(<60 \%)$ and scored $0.9 \%$ out of $1.5 \%$. From the results of interviews with the Regional Technical Implementation Unit of Purwosari as the previous authority of Surak Irrigation Area, the Alliance of Water User Associations (WUAs) located in the Surak Irrigation Area has not been developed because it is still at the stage of collecting contributions to finance the supervision of the sluice gate during the dry months. Thus, it was categorized in bad condition $(<$ $60 \%$ ) and scored $0.15 \%$ out of $0.5 \%$.

The frequency of meetings of the WUA Alliance with observers is irregular, but the discussions were still held. 90-100\% of Alliances of Water User Associations (WUAs) and Water User Associations (WUAs) were present at the meetings. It was found through interviews with the Regional Technical Implementation Unit of Purwosari and the Regional Technical Implementation Unit of Pekalen River Basin. Therefore, this condition scored $0.8 \%$ out of a maximum of $2 \%$. The Alliance of Water User Associations (WUAs) located in the Surak Irrigation Area was still not active enough to carry out irrigation network surveys. It was scored $0.6 \%$ out of the maximum of $1 \%$. 
The Tirto Makmur alliance is quite active in participating in the repair or maintenance of networks caused by natural disasters and was scored $1.8 \%$ out of the maximum of $2 \%$. However, it is still not active enough to obtain contributions for the maintenance of irrigation networks and was scored $0.6 \%$ out of the maximum of $2 \%$. The Tirto Makmur alliance has been quite active in participating in crop planning and water allocations and thus was scored $0.8 \%$ out of the maximum of $1 \%$.

\subsubsection{Summary of Surak Irrigation Area Performance Index}

After the seven aspects were scored, the total irrigation performance index for the Surak Irrigation Area was scored. The irrigation performance index had a score of $77.56 \%$ and is categorized in good condition $(60-80 \%)$.

Table 2. Surak Irrigation Performance Index

\begin{tabular}{|c|c|}
\hline Aspect & $\%$ \\
\hline Physical Infrastructure & 39.1 \\
\hline Water Resource Availability & 5.4 \\
\hline Crop Productivity & 4.4 \\
\hline Supporting Facilities & 7.8 \\
\hline Personnel Organization & 10.8 \\
\hline Documentation & 3.8 \\
\hline Water User Associations (WUAs) & 6.3 \\
\hline Total & 77.56 \\
\hline
\end{tabular}

\subsection{Calculation of Asset Priority}

The priority for rehabilitating damaged assets was obtained from ranking the performance indices from lowest to highest. The evaluation followed the evaluation of the physical infrastructure aspects in scoring the irrigation performance index. The physical assets whose priorities were evaluated are in the form of building assets and channel assets. The total number of these two assets is 215 units, with 191 buildings and 24 channels.

Table 3. Summary of Physical Infrastructure by Condition

\begin{tabular}{|l|c|}
\hline \multicolumn{1}{|c|}{ Aspect } & \% \\
\hline Excellent & 146 \\
\hline Good & 43 \\
\hline Average & 24 \\
\hline \multicolumn{1}{|c|}{ Total } & 213 \\
\hline
\end{tabular}

\subsection{Calculation of Real Costs of Irrigation Operations and Maintenance}

\subsubsection{Calculation of Overtime Wages}

The calculation of overtime wages in an irrigation area depends on the number of observers, sluice guards, and weir operational officers. The Surak Irrigation Area itself has one observer as well as five sluice guards and weir operational officers. Data for overtime wages of observers, sluice guards, and weir operational officers were obtained from the operations and maintenance manual. The resulting wage of observers was IDR 24,000,000 and of sluice guards and weir operational officers was IDR $90,000,000$.

\subsubsection{Field material for Subsections of an Irrigation Area}

Calculation of the demand for field material for an irrigation area's subsections was based on the operations and maintenance manual for the Pekalen River Basin. The material requirements are the result of surveying materials needed for operations and maintenance.

The calculated costs were IDR 17,043,360 for fuel, IDR 12,775,181 for materials for maintaining the sluice gate, IDR 6,110,575 for fieldwork equipment, and IDR 593,250 for the cost of building 
materials. The price for materials for the maintenance of the work residence is non-existent because there are technicalities with the work residence. The total cost for the needs of on-the-field materials for subsections of an irrigation area was found to be IDR $36,522,366$.

\subsubsection{Lubricants and paints for sluice gates}

Demand for lubricants and paints was calculated based on the number and type of sluice gates in the Surak Irrigation Area. From the available data, it was found that the Surak Irrigation Area has two types A sluice gates, 2 type B* sluice gates, and 16 type $\mathrm{C} 2$ sluice gates. Each type of sluice gate has different needs for lubricants and gate painting. The required costs were found to be IDR 10,520,811.

\subsubsection{Heavy Equipment and Tools for Subsections of an Irrigation Area}

The costs of heavy equipment and machinery needs for the subsection of an irrigation area in the field are costs for purchasing vehicles and purchasing fieldwork equipment. Although Surak Irrigation Area still does not have a guard, the prices are still budgeted for the needs of future deployment of a guard. A vehicle's costs were found to be IDR 40,000,000.00, and costs for purchasing fieldwork equipment were found to be IDR 24,192,768.00. Thus, the total costs of equipment and machinery needed for subsections of an irrigation area in the field were found to be IDR 64,192,768.00.

\subsubsection{Business Trips for Regional Technical Implementation Unit Staff, Observers, Sluice Guards, and Weir Operational Officers}

The costs of business trip needs are adjusted to the Regional Technical Implementation Unit's deployment needs to locations in the field. The total budget is designated for one observer and one guard or officer. The resulting costs were found to be IDR 2,700,000.00 per month and IDR 6,264,000.00 per year.

\subsubsection{Other Expenditures for Regional Technical Implementation Unit Staff, Observers, Sluice Guards, and Weir Operational Officers}

Other Regional Technical Implementation Unit staff, observers, sluice guards, and weir operational officers consist of operations and maintenance costs. The included cost items are operational vehicle documents, printing blanks for operation and maintenance activities, photocopies, meetings and food, coaching and training, cropping plan preparation, and emergency maintenance. The total costs were found to be IDR $48,242,890.00$.

\subsubsection{Calculation Cost of Periodic Maintenance}

Of the 21 location points that need to be rehabilitated, 14 of them consist of lining damage. The damages are comprised of collapsed left and right linings. From the survey results, the total volume and area of damage in the Surak Irrigation Area and the resulting total volume of material that needs to be rehabilitated were found to be $66.87 \mathrm{~m}^{3}$. The other 6 points involve damage due to sediment and mud. According to the survey results, the calculated volume of sediments in the Surak Irrigation Area was found to be $84.76 \mathrm{~m}^{3}$.

The volume of damage to structures was calculated based on the conditions and types of damage that occurred to the structures. In the Surak Irrigation Area, 19 assets were found with different kinds of damage. The work required to repair the damage constitutes plasterwork, sediment excavation, river masonry installation, surface masonry installation, and weed clearing.

Rehabilitation or replacement of sluice gates is already included in the analysis of work unit prices according to the dimensions of the sluice gates in the structures. Structure B.SK.10i involves replacement of 2 gear spindles $(b=1.5 \mathrm{~m}, \mathrm{~h}=1.5 \mathrm{~m})$; structure B.MP.5 involves replacement of 2 tertiary sluice gates $(b=0.5 \mathrm{~m}, \mathrm{~h}=0.6 \mathrm{~m})$; and structure B.MP.4 involves replacement of 1 tertiary sluice gate $(b=0.5 \mathrm{~m}, \mathrm{~h}=0.6 \mathrm{~m})$ and another tertiary sluice gate $(\mathrm{b}=0.2, \mathrm{~h}=0.6)$.

The calculation of the volume of materials that need to be rehabilitated in structures and channels is followed by calculating periodic maintenance's quantity and price. There are three aspects of the 
calculation of periodic maintenance: general items, channel rehabilitation, and structure rehabilitation. General items comprise the work required to start channel rehabilitation and structure rehabilitation. General items consist of deployment and return, temporary road construction and village road maintenance, and mutual check and as-built drawings.

The calculation of the construction and channel work volumes was then multiplied by each item's work unit price according to current work unit prices and analyses of work unit prices for all the respective items.

The resulting costs were found to be IDR 89,792,947.29 for general items IDR. 904,623,785.1 for channel work, and IDR 173,081,155.30 for structure work. The total cost required for periodic maintenance was found to be IDR 1,167,497,887.73. To account for VAT, 10\% was added to the cost, and after rounding, the resulting cost was found to be IDR 1,284,247,600.00 (One Billion Two Hundred Eighty-Four Million Two Hundred Forty-Seven Thousand Six Hundred Rupiahs).

\subsubsection{Summary of Real Cost Value of Irrigation Operation and Maintenance Calculations}

After calculating the real cost value of irrigation operations and maintenance, the Surak Irrigation Area's total costs were calculated. Costs of operational activities were found to be IDR 208,506,890.00, and maintenance costs were found to be IDR $1,353,234,758.82$. The total costs of both operations and maintenance activities were found to be IDR 1,561,741,648.82.

\subsection{Rehabilitation of Physical Infrastructure in Surak Irrigation Area}

The rehabilitation of physical infrastructure in the Surak Irrigation Area can be categorized based on the performance index. One hundred forty-six assets need routine maintenance (indices of 90-100\%), 43 assets that need periodic maintenance (indices of $80-90 \%$ ), and 24 assets that require periodic repair (indices of $60-80 \%$ ).

\section{Conclusion}

From the results of the calculations that have been presented, it can be concluded that the Surak Irrigation Area has 21 location points that need rehabilitation, and its irrigation performance index is $77.56 \%$, which falls into the medium condition category (60-80\%). Additionally, if the performance index is categorized using the range from method no.32/2007, it will fall into the same condition. There is no significant difference from the results of the previous research on Pungkit and Barugbug. It caused by the method used is further derived from the existing techniques 32/2007. Therefore, the results are still in the same range. However, the assessment results obtained have more specific details than previous studies. From the survey, there is a total of 213 physical infrastructure assets in the Surak Irrigation Area.

From the calculation of the irrigation performance index, 24 physical infrastructure assets are prioritized for maintenance. These 24 assets consist of 9 waterfall structures, five tapping structures, two side spillway structures, two tapping structures, three culverts, and three bridges. The calculated real cost value for irrigation operations and maintenance of the Surak Irrigation Area is IDR $1,561,741,648.82$. Following the calculation of priority and importance of physical infrastructure assets, 24 assets require repair maintenance, 43 assets need periodic maintenance, and 146 assets requiring routine maintenance.

\section{Acknowledgments}

Gratitude is due to the Regional Technical Implementation Unit of Pekalen River's operational and maintenance staff and the Regional Technical Implementation Unit of Purwosari.

\section{References}

[1] D. A. Zema, A. Nicotra, L. Mateos, and S. M. Zimbone, "Improvement of the irrigation performance in Water Users Associations integrating data envelopment analysis and multiregression models," Agric. Water Manag., 2018, doi: 10.1016/j.agwat.2018.04.032. 
[2] L. Mateos et al., "Irrigation performance before and after rehabilitation of a representative, small irrigation scheme besides the Senegal River, Mauritania," Agric. Water Manag., 2010, doi: 10.1016/j.agwat.2010.01.021.

[3] G. J. Alaerts, "Adaptive policy implementation: Process and impact of Indonesia's national irrigation reform 1999-2018," World Dev., 2020, doi: 10.1016/j.worlddev.2020.104880.

[4] Sobriyah, Sucipto, and A. H. Wahyudi, "The maintenance evaluation of sungkur irrigation system at ponorogo regency," 2013, doi: 10.1016/j.proeng.2013.03.060.

[5] Ministry of Public Works and Public Housing, Peraturan Menteri Pekerjaan Umum Republik Indonesia nomor 13/PRT/M/2012 tentang Pedoman Teknis Inventarisasi Aset Irigasi [Minister of Public Works of the Republic of Indonesia Regulation Number 13/PRT/M/2012 on the Technical Guidelines for Survey of Irrigation Assets]. Indonesia, 2012.

[6] A. E. Elshaikh, X. Jiao, and S. hong Yang, "Performance evaluation of irrigation projects: Theories, methods, and techniques," Agricultural Water Management. 2018, doi: 10.1016/j.agwat.2018.02.034.

[7] Ministry of Public Works and Public Housing Directorate General of Water Resources, Kriteria dan Bobot Penilaian Indeks Kinerja Irigasi Revisi I [Evaluation Criteria and Weights for the Irrigation Performance Index, Revision I]. 2018.

[8] B. E. Bravo-Ureta, D. Higgins, and A. Arslan, "Irrigation infrastructure and farm productivity in the Philippines: A stochastic Meta-Frontier analysis," World Dev., 2020, doi: 10.1016/j.worlddev.2020.105073.

[9] T. Takayama, H. Matsuda, and T. Nakatani, "The determinants of collective action in irrigation management systems: Evidence from rural communities in Japan," Agric. Water Manag., 2018, doi: 10.1016/j.agwat.2018.04.031.

[10] A. Mishra, S. Ghosh, R. K. Mohanty, and P. S. Brahamand, "Performance evaluation of a rehabilitated minor irrigation project and augmentation of its water resource through secondary storage reservoir," Agric. Water Manag., 2013, doi: 10.1016/j.agwat.2013.06.006.

[11] S. Sharaunga and M. Mudhara, "Determinants of farmers' participation in collective maintenance of irrigation infrastructure in KwaZulu-Natal," Phys. Chem. Earth, 2018, doi: 10.1016/j.pce.2018.02.014.

[12] Ministry Of Public Works and Public Housing, Peraturan Menteri Pekerjaan Umum Republik Indonesia nomor 28/PRT/M/2016 tentang Pedoman Analisis Harga Satuan Pekerjaan Bidang Pekerjaan Umum [Minister of Public Works of the Republic of Indonesia Regulation Number 28/PRT/M/2016 on the Guideline of Analysis of Work Unit Prices of Public Works]. 2016.

[13] Ministry Of Public Works and Public Housing, Menteri Pekerjaan Umum Republik Indonesia nomor 12/PRT/M/2015 tentang Eksploitasi dan Pemeliharaan Jaringan Irigasi [Minister of Public Works of the Republic of Indonesia Regulation Number 12/PRT/M/2015 on the Exploitation and Maintenance of Irrigation Networks]. 2015.

[14] Mulyadi, I. Soekarno, S. Natasaputra, Irrigation Performance Assessment By Permen PU No.32/2007 And Masscote Methode Approach With Rapid Appraisal Procedure (Rap) Evaluation At Barugbug Irrigation Area - West Java. Jurnal Irigasi - Vol. 9, No. 2, October. 2014.

[15] R. E. Sijoen, W. Soetopo, L. D. Nugroho, Analisa Indeks Kinerja Dalam Rehabilitasi Daerah Irigasi Pungkit Kecamatan Lopok Kabupaten Sumbawa Dengan Menggunakan Software Pdsda-Pai Versi 1.0. 2015. 